\title{
Piotr Salwa
}

\section{Dialogowość w dawnej noweli włoskiej*}

ABSTRACT. Salwa Piotr, Dialogowość $w$ dawnej noweli włoskiej [Dialogues in the old Italian short stories]. „Przestrzenie Teorii" 9. Poznań 2008, Adam Mickiewicz University Press, pp. 3951. ISBN 978-83-232-1917-0. ISSN 1644-6763.

In the article are discussed various aspects of dialogic character, which appear in Boccaccio's Decameron and which are signalled or discussed by the author himself (a dialogue inside the text, intertextual dialogue, thematised dialogue, a dialogue with the reader and the like). Against this background the narrative strategies used by the so called "imitators" of the Tuscan writer, who discard his innovative view are interesting. Some of them ostentatiously "do not notice" this problem at all, others deprive dialogue of its open and ambiguous character, still others make it fit the needs of political persuasion. This attitude is more precisely illustrated by means of an example of Novelle - Short Stories of Giovanni Sercambi of Lucca and the original novel II Paradiso degli Alberti attributed to Giovanni Cherardi da Prato (these two Tuscan works of literature come from the 15 th century).

Wszelkie ogólniejsze rozważania na temat dawnej nowelistyki włoskiej rozpoczynają się zazwyczaj od nawiązania do Dekameronu Boccaccia. Chociaż na pierwszy rzut oka może się to wydawać pewnego rodzaju skostniałym rytuałem, nieco dokładniejsze spojrzenie pokazuje, iż jest to podejście nie tylko uzasadnione, ale właściwie konieczne. Nie tylko dlatego, że Dekameron jest pierwszym włoskim arcydziełem narracyjnym (porównanie z wcześniejszym zbiorem krótkich narracji znanym jako $I l$ Novellino pokazuje to bardzo wyraziście) i że na długie stulecia stał on się obowiązkowym punktem odniesienia dla autorów uprawiających twórczość prozatorską (przypomnę, że nigdy w całości nie znalazł się on na Indeksie Ksiąg Zakazanych pomimo kontrowersyjnych treści), ale także, a może przede wszystkim, dlatego że Boccaccio poświęca w nim wiele uwagi ogólnym i, chciałoby się powiedzieć, teoretycznym zagadnieniom literackiego komunikowania. Liczne i ciekawe studia, jakie ukazały się $\mathrm{w}$ stosunkowo niedawnych latach, eksplorują dokładniej te aspekty całej obszernej Bokacjuszowej spuścizny, w której słynny zbiór nowel zajmuje pozycję wyjątkową i szczególną ${ }^{1}$, a wynikające z tych do-

" Artykuł jest wersją referatu wygłoszonego na Interdyscyplinarnej Konferencji Naukowej Dramatyczność $i$ dialogowość w kulturze zorganizowanej przez Pracownię Estetyki Literackiej Uniwersytetu im. Adama Mickiewicza i Zakład Teorii Literatury i Poetyki Uniwersytetu Warszawskiego, Kołobrzeg 16-19 października 2007.

${ }_{1}$ Przypomnę tu jedynie F. Bruni, Boccaccio. L'invenzione della letteratura mezzana, Il Mulino, Bologna 1990 oraz Lessico Critico Decameroniano, a c. di R. Bragantini 
ciekań wnioski potwierdzają znaczenie śmiałych dokonań i nowatorskich propozycji toskańskiego autora.

Dialogowość jest jedną z tych kwestii, którym Boccaccio poświęcił wiele uwagi, a jego sposób myślenia może niekiedy zaskakiwać swoją nowoczesnością. Zagadnienie to pojawia się na wielu poziomach narracji Dekameronu, które w tym względzie wzajemnie się dopełniają. Nie od rzeczy będzie rozpocząć nasze rozważania „od środka” tej piętrowej struktury narracyjnej, to znaczy od tzw. „opowieści ramowej”. Pamiętamy, że przedstawia ona 10 młodych osób, które uciekają przed zarazą panującą we Florencji i na dwa tygodnie przenoszą się do podmiejskich posiadłości. Jedną z ich rozrywek jest opowiadanie nowel - odbywa się ono w 10 „odsłonach”, a w trakcie każdej z nich zostaje przedstawionych 10 opowiadań. W zabawie tej dialogowość pełni pierwszoplanową rolę. Nie chodzi o to, że nowelom (które sam Boccaccio określa jako „nowele albo bajki, albo przypowieści, albo historie")2 towarzyszą rozmowy i komentarze - chodzi o to, że nowele są integralną i centralną częścią debat, jakie toczą między sobą uczestnicy spotkań. Opowiadanie bywa ilustracją tezy zapowiedzianej w krótkim wstępie, argumentem i kontrargumentem, nawiązaniem do wcześniejszych wypowiedzi, pytaniem, dowodem itd. - można by tu pokusić się o typologię zgodną ze wskazówkami ówczesnej retoryki, zasadami średniowiecznych debat lub dworskich cours d'amour - a ich następstwo układa się często w ożywioną i ciekawą dyskusję ${ }^{3}$ Odwołując się do znanej terminologii proponowanej niegdyś przez Marię Corti, można by również powiedzieć, że makrotekstem Dekameronu jest właściwie zapis rozmów. Rozmów, które rządzą się ustalonymi na takie właśnie okazje, dość typowymi zasadami (stałe miejsce i pora spotkań oraz stosowanie się do zaleceń osoby, która im „przewodniczy", dbałość o spójność konwersacji, grzeczne respektowanie kolejności zabierania głosu i cierpliwe wysłuchiwanie innych, udzielanie głosu wszystkim uczestnikom). Najczęściej, chociaż nie zawsze, rozmowy te poświęcone są jakiemuś $\mathrm{z}$ góry określonemu zagadnieniu, zaś przed nudą

e P.M. Forni, Bollati Boringhieri, Torino 1995 (w szczególności opracowany przez Bragantiniego rozdzial Dialogo, s. 93-115).

$2 \mathrm{~W}$ oryginale cento novelle, o favole o parabole o istorie (Dec., Proemio, 13; posługuję się kanonicznym wydaniem G. Boccaccio, Decameron, a c. di Vittorio Branca, Accademia della Crusca, Firenze 1976; do tego wydania odsyłam zawsze dodatkowo, cytując Dekameron po polsku); w polskim przekładzie "sto nowel, bajek albo przypowieści" (G. Boccaccio, Dekameron, przeł. E. Boyé, tekst poprawił i uzupełnil M. Brahmer, z oryginałem porównał, przedmową i przypisami opatrzył K Żaboklicki, Ksiązka i Wiedza, Warszawa 1997, t. I, s. 27).

3 Por. G. Getto, Vita di forme e forme di vita nel «Decameron», Petrini, Torino 1966 (w szczególności rozdział La cornice e le componenti espressive del Decameron, s. 1-33).

${ }^{4}$ M. Corti, Principi di comunicazione letteraria, Bompiani, Milano 1976, s. 145-147. 
monotematyczności mają bronić się dzięki zwolnieniu ostatniego $\mathrm{z}$ wypowiadających się, Dionea, z obowiązku respektowania wyznaczonej uprzednio tematyki. Taka perspektywa - sygnalizowana i podkreślana przez Boccaccia expressis verbis ${ }^{5}$ - oferuje propozycje interpretacyjne alternatywne wobec tych, jakie sugeruje sama narracja. Najwyraźniej, jakby w formie „instrukcji czytelniczej”, autor pokazuje to na początku zbioru. Opowieść o świętokradczej spowiedzi Ser Ciappelletta (Dzień I, Nowela 1), który po śmierci zostaje wyniesiony na ołtarze, wydawałaby się naruszać podstawy kultu świętych ${ }^{6}$, ale jej funkcja w dialogu narratorów to ilustracja absolutnie ortodoksyjnej prawdy, że niezbadane są wyroki boskie, a miłosierdzie Stwórcy z cierpliwością znosi błędy wypływające z ludzkiej nieświadomości. Jest ona jednocześnie spełnieniem zalecenia, że wszystkie działania ludzkie powinny zaczynać się „w święte i podziwiania godne imię Tego, kto był twórcą wszystkich rzeczy"7. Opowieść o Żydzie Abrahamie, który nawraca się pomimo korupcji panującej pośród hierarchii kościelnej (Dzień I, Nowela 2), pozornie podejmuje stereotypowe wątki zepsucia obyczajów panującego w Rzymie, pokrętnego rozumowania Żydów oraz dobrego Żyda, który za swe cnoty otrzymuje nagrodę w postaci nawrócenia na chrześcijaństwo, ale w rozmowie służy pokazaniu, iż miłosierdzie boże z cierpliwością znosi również ciężkie i świadomie popełniane grzechy, gdyż „tą drogą Bóg daje dowody niezachwianej prawdy [wiaryl, abyśmy z większą duszy stałością szli za tym, w co wierzymy" 8 . Natomiast kolejna nowela, słynne opowiadanie o trzech pierścieniach (Dzień I, Nowela 3), które mogłoby sugerować, że nie wiadomo, jaka wiara jest prawdziwa, ma być jedynie ilustracją tezy, iż bystrość umysłu i spryt pozwalają inteligentnemu człowiekowi uratować się z każdej opresji. Przecież $\mathrm{w}$ towarzyszącym opowiadaniu fragmencie rozmowy powiedziano już wcześniej, że nie będzie mowy o sprawach boskich, gdyż „o Bogu i o prawdzie naszej wiary już dość rzeczone zostało i wydaje się teraz nie od rzeczy zstąpić ku przypadkom i dziełom ludzkim”.

5 Warto może zwrócić uwage na pełny tytuł zbioru Księga Dekameron zwana Księciem Galeotto, w której zawiera się sto nowel powiedzianych $w$ dziesięć dni przez siedem bialoglów i trzech mlodzieńców, w którym aspekty dialogowości pobrzmiewają dosyć wyraźnie. W pierwszych słowach wprowadzenia do Dnia I odnajdziemy natomiast m.in. słowa „osoby mające później wystąpić zebrały się tutaj i gawędzą społem” (G. Boccaccio, Dekameron, cyt., t. I, s. 25 i 31; Dec., Proemio, 1).

o Por. W. Szkłowski, O prozie. Rozważania $i$ analizy, przeł. S. Pollak, PIW, Warszawa 1964, część Na drodze do stworzenia charakteru jako nowej jedności.

${ }^{7}$ G. Boccaccio, Dekameron, cyt., t. I, s. 47 (Dec., I, 1, 2).

8 Tamże, cyt., t. I, s. 61 (Dec., I, 2, 3).

9 Tamże, cyt., t. I, s. 65 (Dec., I, 3, 3). 
Sygnalizowanie alternatywnych interpretacji jest nawiązaniem dialogu z czytelnikiem, którego wyraźnie nakłania się do aktywnego odbio$\mathrm{ru}^{10}$, a potwierdzenie tego sposobu pojmowania relacji odbiorcy i tekstu znajdziemy we Wstępie i Posłowiu, gdzie autor zabiera głos w pierwszej osobie nie tylko po to, by zasugerować swojej publiczności, iż jego opowiadania można interpretować zgodnie $\mathrm{z}$ wzorami stosowanymi tradycyjnie do rozmaitych, odmiennych gatunków narracji, ale również i po to, by dać wyraz przekonaniu, że to na czytelniku spoczywa głównie odpowiedzialność za interpretację tekstu.

Jakiekolwiek zaś są opowieści moje - jak wszystko inne - mogą szkodliwymi lub pożytecznymi się okazać, zależnie od natury słuchacza. Któż nie wie, że wino jak opój pospołu z pijanicą obok wielu innych zaręczają - jest rzeczą dla zdrowych zbawienną, szkodliwą zasię dla ludzi gorączką trawionych? Mamyż więc dlatego, że gorączkującemu szkodzi, powiedzieć, iż jest zabójcze? [...] Umysł spaczony żadnego slowa w jego prawdziwym nie weźmie znaczeniu. Najszlachetniejsze słowa pożytku mu nie przyniosą, równie jak mniej przystojne nie zdołają splamić duszy czystej [...] Każda rzecz sama w sobie na coś przydatna być może, źle natomiast użyta, znaczne wyrządza szkody. To samo mówię o mych opowieściach ${ }^{11}$.

Dialog ten nabiera konkretnych kształtów i pewnego dynamizmu, jeśli zważyć, że już w pierwszych słowach Boccaccio wyraźnie określa publiczność, do której przede wszystkim się zwraca (chociaż wcale nie musimy wierzyć, że istotnie jego celem jest przyniesienie pociechy kobietom cierpiącym z miłości i zmuszonym do ukrywania swoich cierpień), a później aż dwukrotnie (we Wstępie do IV Dnia i w Posłowiu) mówi o reakcjach odbiorców, przytacza ich głosy krytyczne i polemizuje z nimi, broniąc swoich racji.

Jednak powróćmy jeszcze do dialogu toczącego się pomiędzy narratorami opowieści ramowej i do jego znaczeń. Przeciwstawia on się wyraźnie opisowi dżumy, od którego Boccaccio rozpoczyna swą opowieść. W ogarniętej straszliwą epidemią Florencji zanikły wszelkie cywilizowane kontakty międzyludzkie ${ }^{12}$. Rozmowy prowadzone przez bohaterów

10 Założenie aktywnego odbioru H.-J. Nauschäfer (Boccacio und der Beginn der Novelle. Strukturen der Kurzerzählung auf der Schwelle zwischen Mittelalter und Neuzeit, Fink Verlag, München 1969) uznał za cechę gatunkową noweli. Nie wydaje mi się jednak, aby taka generalizacja była uzasadniona, co staram się wykazać w drugiej części tego szkicu.

11 G. Boccaccio, Dekameron, cyt., t. II, s. 400-401 (oryg. Dec., Conclusione dell'Autore, 8-14).

12 Por. „Wszyscy bezlitośnie tylko o to się starali, aby społeczeństwa z chorymi unikać. [...] Zgromadzali się $w$ domach swoich, gdzie żyli odcięci od świata całego. [...] Liczni, gdy jeszcze zdrowiem się cieszyli, opuszczali w niedoli swoich krewniaków i przyjaciół i tym dawali przykład drugim, którzy, gdy na nich kolej przyszła, to samo czynili, zdając 
służą między innymi odbudowaniu form wytwornego i zgodnego „bycia razem", a przywoływana w nich wizja świata wyraża niewątpliwe przywiązanie do tego, co zostało unicestwione, ale co może i powinno w przyszłości powrócić. Ucieczka z Florencji jest jednak przede wszystkim środkiem zapobiegawczym, mającym uchronić przed śmiertelną i zaraźliwą chorobą - bohaterowie Boccaccia postępują zgodnie z zaleceniami ówczesnych traktatów medycznych ${ }^{13}$. Pośród tych zaleceń wymienia się także dbałość o pogodę ducha i dobry nastrój, które wzmacniają ogólną odporność. Dialog służy więc i takim celom. Jest w tym jednak coś jeszcze. Zastanawiająca liczba 7 kobiet i 3 mężczyzn, stanowiących grupę dekameronowych narratorów, odsyła czytelnika do powszechnie znanych w ówczesnej Toskanii motywów malarskich. Freski przedstawiające Triumf śmierci sugerują, że przyjemna i światowa rozmowa oddala człowieka od myśli o zbawieniu wiecznym, a zatem prowadzi do duchowego upadku. Dialog prowadzony w opowieści ramowej Dekameronu oznacza dokładnie coś przeciwnego: tryumf życia nad śmiercią, jaką przynosi dżuma ${ }^{14}$.

Zainteresowania Boccaccia tymi właśnie kwestiami potwierdza wiele nowel, w których ośrodkiem intrygi czy akcji jest właśnie dialog oraz funkcjonowanie słowa w dialogu. Już w pierwszej noweli Dekameronu wspomnianej przed chwilą opowieści o świętokradczej spowiedzi Ser Ciappelleta - centralną rolę odgrywa specyficzna konwersacja, która służy wykreowaniu nieprawdziwej rzeczywistości. Przykładów takiego użycia słowa znajdziemy w Bokacjuszowym zbiorze wiele ${ }^{15}$. W świecie przedstawionym w nowelach dialog służy także udzieleniu napomnienia lub daniu nauczki, wykazaniu bystrości umysłu lub głupoty, zaatakowaniu adwersarza i obronie własnych racji - bez wątpienia jest on jednym z ważniejszych instrumentów społecznego działania i międzyludzkich relacji. Wirtuozeria w jego konstruowaniu ceniona jest przez Boccaccia wysoko: przynosi ona zawsze korzyści temu, kto ją opanował, jest wyrazem inteligencji i esprit. Nie wpływa na to fakt, że chodzi tu o narzędzie, które może być wykorzystywane w różnych celach - może być środkiem

bliskich na pastwę losu. [...] niejeden człek samotnie z tego świata schodził, nie będąc żegnany łzami i wzdychaniami krewniaków. Miast szlochów rozbrzmiewały żarty, śmiech i wesołość na stypach". (G. Bocc accio, Dekameron, cyt., t. I, s, 33-35; Dec., I, Intr., 2034). Według szacunków Florencja mogła wówczas stracić około $1 / 3$ ludności.

${ }^{13}$ Por. G. Olson, Literature as Recreation in the Later Middle Ages, Cornell University Press, Ithaca and London 1982.

${ }_{14}$ Por. L.B. Ricci, Ragionare nel giardino. Boccaccio e $i$ cicli pittorici del "Trionfo della morte», Salerno Editrice, Roma 1987.

15 Por. G. Getto, Vita di forme e forme di vita nel "Decameron», cyt., rozdział Le novelle dello scambio di illusione e realtà, s. 165-188. 
służącym zarówno do rozwiązywania problemów, jak i oszustwa. Dialog staje się expressis verbis tematem jednego z dni, a sztuka rozmowy, opowiadania $\mathrm{i}$ interakcji staje się tematem środkowej, czyli centralnej noweli całego zbioru ${ }^{16}$.

Kwestie dialogowości w Dekameronie nie tylko pojawiają się - jak widać - na różnych poziomach narracji i w różnych kontekstach, ale są również poddawane oglądowi w różnych perspektywach i z różnych punktów widzenia. Wieloaspektowość tego ujęcia trudno sprowadzić do jakiegoś spójnego poglądu czy teoretycznego założenia: niesprowadzalna do jedności wieloaspektowość jest zresztą jedną z najbardziej charakterystycznych cech arcydzieła Boccaccia i narzuca się nie tylko w przypad$\mathrm{ku}$ omawianej tu problematyki. Warto zatem podkreślić nowatorstwo Boccaccia $w$ takim podejściu do tekstu literackiego - wyznacznikiem kultury tamtej epoki jest przecież dążenie do jednoznacznych interpretacji, będących odzwierciedleniem jednoznacznej zawsze prawdy, oraz głęboka nieufność do tekstów „otwartych". Warto też może od razu powiedzieć, że takie właśnie propozycje Boccaccia zostały odrzucone przez późniejszych autorów, tradycyjnie określanych jako jego naśladowcy. Dotyczy to również pojmowania dialogowości.

Jest to kwestia istotna, jako że Dekameron zyskał bardzo szybko dużą popularność, a w trakcie dziesięcioleci, które nastąpiły po jego pojawieniu się, na całym Półwyspie Apenińskim, nie tylko w Toskanii, nowela stała się formą literacką tak częstą, że uznano ją nawet za emblematyczną dla włoskiego życia literackiego XIV-XVI wieku. Zbiór nowel sławnego pisarza stał się dla mniej utalentowanych narratorów obowiązkowym punktem odniesienia, trudno jednak te relacje określać wyłącznie jako naśladownictwo (często zresztą prowadzące do bardzo miernych efektów), gdyż ujawniał się tu także dość wyraźnie opór przeciwko nowatorstwu Boccaccia. Widać to właśnie min. na podejściu do interesujących nas kwestii.

Odrzucenie form dialogowości zaprezentowanych w Dekameronie dokonywało się przy jednoczesnym naśladowaniu innych rozwiązań narracyjnych, jakie proponował Boccaccio, lub przy ostentacyjnym deklaro-

16 Por. Dzień VI: „w którym [...] opowiada się o tych, co trafnym powiedzeniem odparli przytyk w nich godzący albo ciętą odpowiedzią [...] uniknęli straty, niebezpieczeństwa czy wstydu". Pierwsza nowela tego dnia - będąca zarazem centralnym opowiadaniem w zbiorze, a zatem zajmująca pozycję „strategiczną" z kompozycyjnego, retorycznego i perswazyjnego punktu widzenia - poświęcona jest sztuce opowiadania jako elementowi konwersacji: „Pewien szlachcic obiecuje pani Oretcie, że gdy jego opowieści słuchać będzie, droga szybko jej minie ..." (G. Boccaccio, Dekameron, cyt., t. I, s. 469, t. II, s. 11; Dec., VI, Intr. 1 oraz 1, 1). 
waniu podziwu i szacunku dla autora $z$ Certaldo ${ }^{17}$. W moim przekonaniu była to postawa świadomie polemiczna, a nie zwyczajny brak zrozumienia nowatorskich poczynań wielkiego pisarza. Ostentacyjnie podkreślana dialogowość okazuje się zatem propozycją nie do zaakceptowania, kwestią sporną, ale już w pewien sposób roztrząsaną i uświadamianą, zapewne na poziomie intuicyjnym i praktyki pisarskiej, a nie pogłębionej teoretycznej refleksji. Warto jednak przypomnieć, że wkrótce François Rabelais - któremu tradycja toskańska i włoska były nieobce, tak jak większości wykształconych Europejczyków XVI w. - podejmie te zagadnienia w sposób o wiele bardziej przemyślany w Przedmowie autora do Gargantui i Pantagruela, $1534^{18}$. Strategie wybierane przez włoskich nowelistów idących śladami Boccaccia bywały bardzo rozmaite, miały jednak pewną wspólną cechę i zdawały się opierać na podobnych założeniach: chodziło w nich najczęściej o wyznaczenie wyraźnych granic czytelniczej interpretacji, niedopuszczenie do nadmiernej swobody i aktywności odbiorcy. Niektórzy zrezygnowali w ogóle z opowieści ramowej i wewnętrznego dialogu, udzielając głosu jednemu tylko autorskiemu głosowi. Franco Sacchetti (Il Trecentonovelle, ok. 1400) świadomie ogranicza się przy tym do pozbawionych większych aspiracji anegdot i ,historyjek", łączących się ze sobą na podstawie luźnych skojarzeń, od czasu do czasu wplatając do opowiadań ogólniejsze, ale raczej nieskomplikowane obserwacje będące wynikiem jego własnych doświadczeń życiowych. Jest to $\mathrm{z}$ pewnością przemyślany wybór, Sacchetti ma bowiem w swoim dorobku utwory o wiele ambitniejsze zarówno jeśli chodzi o formę artystyczną (Libro delle rime - poezje, w tym wiele pisanych $\mathrm{z}$ myślą o akompaniamencie muzycznym), jak i o treści intelektualnej (Sposizione dei Vangeli - objaśnienia do ewangelii). W zbiorze nowel kreuje się jednak na dość pospolitego gawędziarza - uomo discolo e grosso - który swoimi opowiadaniami pragnie jedynie przynieść chwilę rozrywki i zapo-

17 Kwestie te omawiam m.in. P. Salwa, Historie zmyślone - historie prawdziwe, Semper, Warszawa 2000.

${ }_{18}$ Rabelais podkreśla wyraźnie aktywną rolę czytelnika: „... przystoi wam owa roztropność, abyście umieli węszyć, czuć i oceniać owe piękne księgi suto kraszone omastą, niewinne a zwinne, celne a strzelne. Później zasię, przez pilne wgłębianie się a baczne rozmyślanie, uda wam się skruszyć kość a wyssać posilny szpik, czyli to, co rozumiem przez one pitagorejskie symbole, w nadziei, iż jesteście dość bystrzy a sposobni do takiego czytania [...] Czy wy naprawdę sumiennie mniemacie, iż kiedykowiek Homer, pisząc Iliadę i Odyseję, miał na myśli owe alegorie, w jakie go ustroili Plutarch, Heraklides poncki, Eustatius, Phornutus, i to, co $\mathrm{z}$ nich ukradł Policjan? [...] Jeśli $\mathrm{w}$ to nie wierzycie, dla jakiej przyczyny nie mielibyście uczynić tak samo z tymi uciesznymi i nowymi kroniczkami..." (por. Rabelais, Gargantua i Pantagruel, przeł. T. Żeleński Boy, PIW, Warszawa 1955 , s. 4-6). 
mnienia prostym ludziom wiecznie gnębionym przez los ${ }^{19}$. Można wprawdzie domyślać się, kim mieliby być uczestnicy owej gawędy - świat, w którym się ona zamyka, to dość ograniczony świat codziennej egzystencji i zainteresowań średnio zamożnych i niezbyt wykształconych mieszczan - są oni jednak sprowadzeni do roli słuchaczy, godzących się na milczenie w obecności narratora. Masuccio Salernitano (Il Novellino, 1476) kreuje się natomiast na autora dworskiego: każde opowiadanie poprzedza listem dedykacyjnym adresowanym do postaci znanej w świecie arystokratycznym, na końcu każdej noweli zamieszcza zaś firmowaną przez siebie explicite, „zewnętrzną” interpretację i morał, nie oczekując żadnej konkretnej odpowiedzi. Anonimowy autor florencki znany jako Ser Giovanni (Il Pecorone, ok. 1380) wprowadza wprawdzie dialog do swej schematycznej, a zarazem chaotycznej, szczątkowej opowieści ramowej, ale czyni to tak niezgrabnie, że niektórzy krytycy dostrzegli w nim raczej świadomą parodię tej konwencji20.

Ciekawsze perspektywy na kwestię dialogowości otwierają jednak dwa inne utwory zaliczane zwyczajowo do tradycji nowelistycznej (chociaż można by mieć co do tego pewne zastrzeżenia). Oba charakteryzują się rozbudowaną opowieścią ramową nawiązującą do modelu znanego z Dekameronu. W Nowelach Giovanniego Sercambiego (ok. 1400) postać prezentująca wszystkie bez wyjątku nowele - określane zresztą w tekście jako exempla - nie prowadzi dialogu z nikim. Jej wystąpienia są pewnego rodzaju widowiskiem, który co najwyżej wzbudza krótkie komentarze pozbawione jakichkolwiek akcentów polemicznych. Te „występy" stanowią często tylko jedną z części większego spektaklu, na który składają się poza tym popisy muzyczne, tańce, recytacje poezji dworskich i religijnych. Zadanie polegające na prezentowaniu zabawnych i budujących opowieści powierza narratorowi przywódca całego zgromadzenia, któremu uczestnicy przyrzekają całkowite posłuszeństwo - jest to więc funkcja niejako oficjalna, związana $z$ autorytetem, którego nie wolno kwestionować. Autorytarna jest także stosowana retoryka: dedykacje, morały, sentencje, gwałtowne krytyki, a nawet inwektywy składają się na perswazję ciężką i redundantną, jednostronną i schematyczną. Odpowiada temu sposób konstruowania świata przedstawionego: postawy

19 „[...]zważywszy, że ludzie lubią opowiadania o rzeczach niecodziennych, szczególnie zaś takie lektury, których zrozumienie bez trudu przychodzi, a przede wszystkim takie, które przynoszą pocieszenie, dzięki któremu do licznych naszych strapień trochę śmiechu domieszać się może" (F. Sacchetti, Il Trecentonovelle, a c. di V. Marulli, Salerno Editrice, Roma 1996, Proemio, 1; tłum. P.S.).

20 Zob. C. Muscetta, Struttura del "Pecorone», „Siculorum Gymnasium”, nuova serie, anno XX, nr 1 (gennaio-giugno 1967), s. 1-35; Id., Le ballate del «Pecorone», w: Studi in onore di Carmelina Naselli, Università di Catania, Catania 1968, t. II, s. 161 i nast. 
radykalnie negatywne lub pozytywne, postaci zawsze jednoznacznie określone jako przykład do unikania - exemplum deterrens (na ogół) lub naśladowania - exemplum hortans ( $\mathrm{z}$ rzadka), oczywiste i nie podlegające dyskusji normy, surowe i bezwzględne konsekwencje tworzą system, w którym nie ma miejsca na wahania. Społeczność przedstawiona w opowieści ramowej nie prowadzi dialogu, ponieważ wszystko jest (a właściwie powinno być) jasne i oczywiste. Wspólnota ta jest wprawdzie dobrowolna, lecz jej uczestnicy szybko rezygnują z wolności, oddając wszystko (łącznie $\mathrm{z}$ własnymi pieniędzmi) $\mathrm{w}$ ręce władzy. Tylko rezygnacja $\mathrm{z}$ wolności - powiada Sercambi - pozwoli uniknąć grzechu i gniewu bożego.

Tę perspektywę komplikuje pojawianie się od samego początku aluzji, których dokładniejsze znaczenie nie jest wprawdzie dla nas zawsze jasne, ale których obecność - już sama przez się znacząca - jest poza wszelką dyskusją. Te wyraźne odniesienia do rzeczywistości pozatekstowej i do konkretnych osób pokazują, iż zbiór nowel Sercambiego jest wypowiedzią skierowaną "na zewnątrz". Przedstawiana w opowiadaniach tematyka i wartościowanie postaw nabierają zatem właściwego znaczenia dopiero wówczas, jeśli podejmie się próbę rekonstrukcji kontekstu pozaliterackiego, w jakim miały funkcjonować, a także kiedy powiąże się ten utwór $\mathrm{z}$ innymi tekstami tego samego autora. Teksty te nie mają charakteru literackiego (są to przede wszystkim bardziej znane od nowel Kroniki), ale są powiązane ze zbiorem opowiadań w różnoraki sposób: łączą je nie tylko pojawiające się w nich wspólne wątki narracyjne, lecz także moment powstania i - zapewne - autorskie motywacje ${ }^{21}$. Te „podskórne" kwestie dotyczą ważnych wówczas spraw politycznych i wartości ideologicznych. Sercambi był postacią znaną ze swej kontrowersyjnej działalności publicznej, a zbiór nowel służył mu do przedstawienia argumentacji uzasadniającej i tłumaczącej jego decyzje i działania ${ }^{22}$. Swoje pisarskie działania pojmuje on więc instrumentalnie: jego nowele to

21 W Nowelach oraz w ostatniej części Kronik pojawia się kilka tych samych opowiadań. Część ta powstała po kilkuletniej przerwie: Sercambi zapowiedział wcześniej zakończenie pracy nad Kronikami, lecz po r. 1400 wrócił do pisania - jak sam wyznaje, pod presją okoliczności. Powtarzanie się opowiadań wskazywałoby na to, że Nowele powstały mniej więcej w tym samym czasie. Rok 1400 byl w życiu Sercambiego niezwykle ważny: pełniąc w rodzimej Lukce najwyższy republikański urząd „chorążego sprawiedliwości” gonfaloniere di giustizia - doprowadził on wówczas do zamachu stanu, w którym obalono dotychczasowy ustrój i wprowadzono rządy autorytarne Paola Guinigiego. Polityka ta nie znalazła uznania (po niespełna 30 latach Lukka ponownie stała się republiką), a Sercambi niewątpliwie musiał stać się obiektem krytyki. Wydaje się prawdopodobne, że prawdziwą inspiracją do napisania Nowel i powrotu do pisania Kronik mogła być chęć odzyskania utraconego dobrego imienia i prestizu.

${ }^{22} \mathrm{Na}$ ten temat pisze szerzej - P. Salwa, Narrazione, persuasione, ideologia. Una lettura del «Novelliere» di Giovanni Sercambi, lucchese, Pacini Fazzi, Lucca 1991. 
wypowiedź zmierzająca do uzyskania konsensusu. Przyjęcie jego argumentacji powinno wyrazić się $\mathrm{z}$ jednej strony szacunkiem i poparciem politycznym współobywateli, z drugiej zaś względami władcy, wyższą pozycją w organach władzy i na dworze signora. Opowieść ramowa przedstawia strony układu, w którym taki konsensus miałby się zrealizować: autor - władca - współobywatele, tworząc przy tym potencjalną przestrzeń dialogu, pozwalając domyślać się jego potrzeby i sensu. (W jednym fragmencie owa potencjalność wyraźniej się zresztą konkretyzuje: w grupie nowel nawiązujących tematycznie do epizodów z dziejów dawnego Rzymu narrator polemizuje ze swym mocodawcą wyrażającym entuzjastyczny podziw dla wielkości Wiecznego Miasta - nie trzeba dodawać, że w XV-wiecznej Italii była to postawa o wyraźnych konotacjach politycznych) ${ }^{23}$. Czy jednak Sercambi zakłada, iż jakiś dialog mógłby rzeczywiście mieć miejsce i chce go w pewien sposób sprowokować, czy też raczej stara się on swoją wizje świata narzucić? Kto miałby ewentualnie zabrać głos w dialogu, w którym Nowele Sercambiego byłyby tylko wypowiedzią jednej ze stron? Jaka byłaby rola partnerów? Nie wydaje się, aby dzieło Sercambiego mogło zachęcać do wymiany poglądów. Tworząc przestrzeń dla dialogu i zarazem nie dopuszczając jego możliwości, autor zdecydowanie podkreśla swoje stanowisko. Zabiera głos jako pisarz i kronikarz, ale nie oczekuje dyskusji. Fakty zdają się też wyraźnie wskazywać, iż tak jak w świecie wewnątrztekstowym, tak i w rodzinnym mieście autora, toskańskiej Lukce, dla takiego dialogu nie przewidziano miejsca, a w każdym razie nikt go nie podjął, zaś jego potencjalni uczestnicy argumentację autora najwyraźniej i zdecydowanie odrzucili. Władca, którego Sercambi wyniósł na tron, nie stworzył mu dalszych możliwości kariery politycznej (choć za dawne zasługi odwdzięczył mu się w stosownej chwili, opłacając z państwowej kasy wystawny pogrzeb), a współobywatele zignorowali zbiór nowel. W czasie, gdy nowelistyka cieszyła się w Italii i w Europie ogromną popularnością zbiór Sercambiego został całkowicie zapomniany ${ }^{24}$.

Drugim utworem, w którym zagadnienie dialogowości pojawia się w interesującej perspektywie jest Il Paradiso degli Alberti (ok. 1420) przypisywane Giovanniemu Gherardi da $\operatorname{Prato}^{25}$. Opowieść ramowa prze-

${ }^{23}$ Zob. P. Salwa, Il mito di Roma nelle novelle di Giovanni Sercambi, "Testo" 11, 1986, s. 38-49.

24 Pierwsza pełna edycja krytyczna pojawiła się dopiero w 1972 r. (G. Sercambi, Novelle, a c. di G. Sinicropi, Laterza, Bari 1972).

${ }_{25}$ Jest to zagadkowy tekst, którego datowanie i atrybucja autorska pozostają właściwie hipotetyczne, odkryty i cześciowo zrekonstruowany w II poł. XIX w. przez wybitnego filologa rosyjskiego Aleksandra Wiesiołowskiego. Tekst ten był wcześniej przedmiotem manipulacji ze strony florenckiego erudyty Gaetana Cioniego, ale wszystkie towarzyszące temu okoliczności nie zostały wyjaśnione. 
waża tu nad samymi nowelami - objętościowo i znaczeniowo - do tego stopnia, że trudno właściwie traktować ten utwór jako zbiór nowelistyczny wzorowany na Dekameronie (zresztą pierwszy jego wydawca określił go jako romanzo, czyli powieść i nadał mu tytuł, który może wzbudzać pewne zastrzeżenia). Jest to odtwarzane po latach wspomnienie $z$ toczących się w eleganckiej i pogodnej atmosferze towarzyskich spotkań, podczas których działo się wiele rzeczy, lecz pamięć narratora koncentruje się przede wszystkim na toczących się tam wówczas debatach. Opowiadania mają sens jedynie jako element szerszego dialogu, w którym mogą pełnić najróżnorodniejsze funkcje: pojawiać się w charakterze przykładu, służyć jako dowód lub jako argument, proponować retoryczną quaestio lub temat do dalszych rozważań, przenosić w świat komizmu i wykluczać z poważnej debaty. Nawiązując do właściwej funkcji średniowiecznych exemplów, nowele mają być często konkretną ilustracją ogólniejszych kwestii, a ich celem jest przybliżenie i objaśnienie teoretycznej i abstrakcyjnej dyskusji w sposób zrozumiały dla słuchaczy nienawykłych do tego rodzaju rozważań ${ }^{26}$. Bezpośrednie znaczenie owych debat wynika z podejmowanej tam różnorodnej problematyki: mowa jest o lokalnych tradycjach, o zbiorowej pamięci, o dawnej i współczesnej historiografii, o interpretacji literatury i poezji, o prawdzie i diabelskich ułudach, o pochodzeniu nazw geograficznych, o formach miłości, o ustrojach politycznych i o dobrych rządach. Wydaje się jednak, że najbardziej istotny sens owego dialogu leży gdzie indziej. Wiele miejsca poświęca autor opisowi procesu, w wyniku którego powoli kształtuje się towarzystwo uczestniczące $\mathrm{w}$ dialogu i stanowiące idealną społeczność. Proces ten ma znaczenie symboliczne ${ }^{27}$. Najpierw stara feudalna arystokracja toskańska nawiązuje bliskie, równouprawnione więzi z przedstawicielami komuny miejskiej i mieszczańskich władz Florencji, a dzieje się to w miejscu, w którym niegdyś toczyły się krwawe, bratobójcze walki. Zgoda jest możliwa, gdyż wszystkich łączy to samo przywiązanie do ojczyzny, ta sama tradycja i kultura. Następnie pierwszoplanową rolę zaczyna odgrywać miasto, a w nim elita złożona $\mathrm{z}$ humanistów piastujących wysokie urzędy

${ }^{26}$ Część debat, poruszających bardziej złożone zagadnienia lub kwestie polityczne, toczy się zresztą w węższym gronie, na ogół wcześnie rano, kiedy kobiety jeszcze śpią.

27 Wrawdzie główni protagoniści opisywanych spotkań to postaci historyczne, jednak trudno uznać Il Paradiso degli Alberti za relację z wydarzeń, które rzeczywiście miały miejsce (por. H. Baron, Giovanni Gherardi da "Pratos Paradiso degli Alberti”, w: tegoż, Humanistic and Political Literature in Florence and Venice at the Beginning of the Quattrocento, Harvard University Press, Cambridge (Mass.) 1995, s. 13-37. Przekonująca argumentacia Barona podważa tezy Wiesiołowskiego). Pojawianie się w fikcji literackiej postaci określanych nazwiskami historycznymi ma w dawnej prozie włoskiej szczególne konotacje - zagadnienia te wykraczają jednak poza ramy naszych rozważań. 
komunalne, polityków, artystów i intelektualistów przybywających z różnych regionów Italii ${ }^{28}$. Do nich dołączają $\mathrm{w}$ końcu na własną prośbę przedstawiciele zamożnego kupiectwa, a centralnym miejscem staje się rezydencja światłego, otoczonego szacunkiem i sympatią młodego i bogatego patrycjusza. Grupa ta powiększa się ciągle o nowe osoby, które wtapiają się $w$ ogół ${ }^{29}$. Sens dialogu polega więc na tym, że zakłada on pewną podstawową wspólnotę i służy wzmocnieniu jej spójności, stając się swoistym rytuałem. Wspólnota jest dobrowolna, a sam fakt prowadzenia rozmowy podkreśla troskę o to, aby dotrzeć do wszystkich, pozyskać jak największe zaangażowanie, poszerzyć obszar wspólnych przekonań. Służy temu konsekwentne unikanie radykalnych rozwiązań - tolerancja, zaakceptowanie wielości punktów widzenia, otwarcie na kompromis wydają się decydujące dla określenia tożsamości owej zbiorowości. Ożywione dyskusje czy konfrontowanie poglądów nie prowadzą tu do konfliktu: dialogowość jest główną podstawą funkcjonowania tego świata. Il Paradiso degli Alberti to utwór, który powstał w latach zagrożenia niepodległości państwa florenckiego, targanego przy tym wieloma konfliktami wewnętrznymi ${ }^{30}$. Dialog jest propozycją, która miała być w założeniu odpowiedzią na wyzwanie chwili: jedność polityczna miała opierać się na wspólnocie kultury. Il Paradiso degli Alberti jest utworem diametralnie przeciwstawnym - w perspektywie literackiej, ideologicznej, pragmatycznej - wobec Nowel Sercambiego, spotkal go jednak ten sam los: zapomnienie.

Jak widać, dawna włoska - a raczej toskańska - nowelistyka nawiązująca do Dekameronu odeszła dość daleko od takiego rozumienia dialogowości, jakie sygnalizował w swoim zbiorze Boccaccio. Można chyba jednak przypuścić, że dzięki autorowi z Certalda zagadnienie to w ogóle pojawiło się $\mathrm{w}$ polu widzenia niektórych ówczesnych pisarzy uprawiających krótkie formy narracyjne. Potraktowali je oni w sposób świadczący o ich samodzielności i - nie wahałbym się powiedzieć - twórczym podej-

28 Florencja w owym czasie nie obawia się powierzania najwyższych stanowisk „cudzoziemcom" przybywającym z innych stron Italii, lecz lojalnie dla niej pracującym; trzej wybitni kanclerze florenccy XV w. (Coluccio Salutati, Leonardo Bruni, Poggio Bracciolini) nie pochodzili z Florencji.

${ }^{29}$ Zob. P. Salwa, "Il Paradiso degli Alberti»: la novella impigliata, w: La novella italiana, Atti del Convegno di Caprarola, 19-24 settembre 1988, Salerno Editrice, Roma 1989 , t. II, s. 755-769 (rozważania te podejmuję także w rozdziale W poszukiwaniu kompromisu: Giovanni Gherardi da Prato (atr.), "Il Paradiso degli Albert» w cytowanej wyżej książce Historie zmyślone - historie prawdziwe, s. 71-117).

${ }^{30} \mathrm{Na}$ ten temat zob. H. Baron, Humanistic and Political Literature in Florence and Venice at the Beginning of the Quattrocento, op. cit. oraz A. Lanza, Polemiche e berte letterarie nella Firenze del primo rinascimento (1375-1449), seconda edizione completamente rifatta, Bulzoni, Roma 1989. 
ściu do wzorca stworzonego przez podziwianego mistrza. Nie tylko zwrócili oni uwagę na sugestie Boccaccia, ale także umieli zręcznie rozwinąć je i wykorzystać do swoich celów. Znaczenie Dekameronu - jak każego zapewne arcydzieła - polegało często na „stawianiu kwestii”, które kolejni autorzy mogli potem rozwijać i rozwiązywać sami. Kwestia dialogowości literatury okazała się jedną z atrakcyjniejszych. Nowele Sercambiego i Il Paradiso degli Alberti Gherardiego da Prato z pewnością nie odegrały większej roli w dziejach literatury włoskiej - niewątpliwie są one jednak dobrymi przykładami eksperymentowania z różnymi aspektami narracji. Nieudane eksperymenty bywają równie ciekawe jak udane - o ile można $\mathrm{z}$ nich wyciągnąć pouczające wnioski. 